\title{
Mechanism of the anti-angiogenic effect of Avemar on tumor cells
}

\author{
NILÜFER GÜLMEN IMIR ${ }^{1,2}$, ESRA AYDEMIR $^{3}$ and ECE ŞIMŞEK ${ }^{4}$ \\ ${ }^{1}$ Department of Biology Education; ${ }^{2}$ Life Sciences Institute, Department of Biology; \\ ${ }^{3}$ Department of Biology, Akdeniz University; ${ }^{4}$ Department of Nutrition and Dietetics, \\ Antalya School of Health, Akdeniz University, Antalya 07058, Turkey
}

Received May 4, 2017; Accepted December 1, 2017

DOI: $10.3892 / 01.2017 .7604$

\begin{abstract}
Avemar, a derivative of fermented wheat germ extract, is a non-toxic and natural compound that is used as a dietary supplement by cancer patients undergoing chemotherapy and radiotherapy. Avemar has numerous biological activities, and several recent studies have reported that it may also have metastatic and anti-angiogenic effects. In the present study, the mechanism of the anti-angiogenic effect of Avemar on human cancer cells was investigated. The human cell lines NCI-N87 (gastric tubular adenocarcinoma), PC3 (prostate carcinoma), HeLa (endocervical adenocarcinoma) and A549 (lung adenocarcinoma) were treated with various doses $(400,800,1,600$ and 3,200 $\mu \mathrm{g} / \mathrm{ml})$ of Avemar, and the changes in mRNA and protein levels of two important markers of angiogenesis, vascular endothelial growth factor (VEGF) and cyclooxygenase-2 (Cox-2), were assessed by reverse transcription-quantitative polymerase chain reaction and ELISA. VEGF and Cox-2 protein and mRNA levels were significantly lower in Avemar-treated cells than in untreated cells. The data suggest that Avemar may exert an anti-angiogenic effect on cancer cells. Thus, it is suggested to medical doctors as a potential agent for the anti-angiogenic treatment of cancer.
\end{abstract}

\section{Introduction}

Angiogenesis, the physiological formation of new blood vessels from pre-existing ones (1), serves a central role in human physiology during fetal development, wound healing, tissue repair following surgery or trauma, menstruation, cancer, and various ischemic and inflammatory diseases (2). However, unregulated angiogenesis may result in angiogenic diseases, including diabetic retinopathy, rheumatoid arthritis, inflammatory diseases, or tumor growth and metastasis $(3,4)$. As cancer growth is associated with angiogenesis, the inhibition of angiogenesis is a promising therapeutic strategy in cancer

Correspondence to: Dr Nilüfer Gülmen Imir, Department of Biology Education, Akdeniz University, Office 145 Education Faculty Building, Konyaaltı, Antalya 07058, Turkey

E-mail: ngimir@akdeniz.edu.tr

Key words: angiogenesis, Avemar, cyclooxygenase 2, vascular endothelial growth factor treatment. Furthermore, understanding the mechanisms of angiogenesis inhibition well enough to manipulate it may lead to numerous therapeutic possibilities.

Avemar (fermented wheat germ extract) is produced by the industrial fermentation of wheat germ. Avemar is a completely natural and non-toxic compound that is used clinically as a dietary supplement for cancer patients undergoing chemotherapy and radiotherapy (5-9). It is known to have certain biological effects due its major components, 2-methoxy-benzoquinone and 2,6-dimethoxy-benzoquinone. Additionally, Avemar has been demonstrated to be associated with anaerobic glycolysis, the pentose cycle and ribonucleotide reductase enzymes; to exert significant anti-proliferative effects in a broad spectrum of tumor cell lines; and to possess the ability to kill tumor cells by inducing apoptosis through the caspase-poly ADP-ribose polymerase pathway $(5,10)$. Furthermore, Avemar was reported to be an effective adjuvant agent in cancer treatment for several types of cancer. such as breast, colon, lung and prostate cancer (11). However, the mechanism of the anti-angiogenic effect of Avemar is unclear. Numerous studies have investigated cytotoxic effects of Avemar on nearly all types of cancers that's why we did not do any cell viability in this project. Therefore, the Avemar concentrations were determined according to the literature (11-14). The main aim of the present study was to determine the effects of Avemar on angiogenesis. Therefore, the present study focused on molecular target genes associated with angiogenesis, vascular endothelial growth factor (VEGF) and cyclooxygenase-2 (Cox-2), to evaluate the anti-angiogenic effect of Avemar on tumor cells.

\section{Materials and methods}

Cell lines and Avemar. The human gastric carcinoma cell line NCI-N87, human prostate cancer cell line PC3, human cervical carcinoma cell line HeLa, and human lung adenocarcinoma cell line A549 were purchased from ATCC (Manassas, VA, USA). All cells were grown in Dulbecco's modified Eagle's medium (Gibco; Thermo Fisher Scientific, Inc., Waltham, MA, USA), supplemented with $10 \%$ heat-inactivated fetal bovine serum (Gibco; Thermo Fisher Scientific, Inc.), $2 \mathrm{mM}$ glutamine, and $1 \%$ penicillin/streptomycin/neomycin in a humidified incubator $\left(5 \% \mathrm{CO}_{2}\right.$ in air at $\left.37^{\circ} \mathrm{C}\right)$. Avemar was donated by Biropharma USA Inc. (New York, NY, USA). The Avemar was stored as dried powder at $4^{\circ} \mathrm{C}$ in a bottle until use. 
Prior to use, it was freshly prepared in sterile water to a final concentration of $400 \mu \mathrm{g} / \mathrm{ml}$. The solution was centrifuged to remove indissoluble materials and then filtered with a $0.22-\mu \mathrm{m}$ filter.

Determination of VEGF and Cox-2 levels by ELISA. A549, PC3 and NCI-N87 cells release VEGF protein constitutively. The augmented release of VEGF protein after $48 \mathrm{~h}$ was determined in response to serum starvation in PC3 and NCI-N87 cells, and in response to $1,000 \mathrm{U} / \mathrm{ml}$ tumor necrosis factor $\alpha$ (TNF- $\alpha$ ) in A549 cells (15). In our previous study, the basal VEGF protein levels were determined at 24, 48 and $72 \mathrm{~h}$ following seeding of HeLa cells $\left(5 \times 10^{3}\right.$ cells/well) without any stimuli (16).

A human VEGF ELISA kit (cat. no., ENZ-KIT156; Enzo Life Sciences, Inc., Farmingdale, NY, USA) was used according to the manufacturer's protocols in order to determine the possible effects of Avemar on VEGF levels in tumor cells. Briefly, $5 \times 10^{3}$ cells were plated in each well of a 96 -well plate and were treated with various concentrations $(400,800,1,600$ or $3,200 \mu \mathrm{g} / \mathrm{ml}$ ) of Avemar for 24 or $48 \mathrm{~h}$. Samples $(100 \mu \mathrm{l})$ were then added to the microplates containing VEGF-specific monoclonal antibodies, and the mixtures were incubated for $2 \mathrm{~h}$ at room temperature. The plates were then washed three times to remove any unbound substances. Enzyme-linked polyclonal antibodies specific for VEGF were then added to the wells, and the mixtures were incubated for $2 \mathrm{~h}$ at room temperature, prior to a further wash to remove any unbound antibody or enzyme reagent. The substrate solution was subsequently added to the wells, and the reaction resulted in the development of a blue color, the intensity of which was proportionate to the amount of VEGF bound in the initial step. Following quenching to cease color development, the intensity of the color was measured at $450 \mathrm{~nm}$ with a Multiskan GO Microplate Spectrophotometer (Thermo Fisher Scientific, Inc.) and compared to a standard curve.

The Cox-2 concentration was measured using a human Cox-2 ELISA kit (cat. no., ADI-900-094) provided by Enzo Life Sciences, Inc. Samples were prepared by extracting Cox-2 from the cells and stock solutions were prepared according the manufacturer's protocol. Briefly, the cells were harvested and medium was removed. The cells were re-suspended in radioimmunoprecipitation assay (RIPA) buffer $(25 \mathrm{mM}$ Tris, pH 7.4, 0.15 M KCl, 1\% NP-40, 5 mM EDTA, 0.5\% Sodium deoxycholate, $0.1 \%$ SDS). Samples were prepared by sonicating cells in RIPA buffer for 5 cycles of $30 \mathrm{sec}$, in $1 \mathrm{~min}$ intervals on ice. Samples were then added the microplate. The plate was incubated at $37^{\circ} \mathrm{C}$ for $1 \mathrm{~h}$, then washed prior to the addition of a labeled antibody. The plate was incubated at $4^{\circ} \mathrm{C}$ for $30 \mathrm{~min}$, washed, and a substrate solution was added. The reaction was stopped and absorbance was measured at $450 \mathrm{~nm}$ using a Multiskan GO Microplate Spectrophotometer. Protein concentrations were calculated with reference to the standard curve.

Total RNA isolation and reverse transcription-quantitative polymerase chain reaction $(R T-q P C R)$. All tumor cell lines were plated in 6 -well plates $\left(3 \times 10^{6}\right.$ cells/well) and allowed to attach for $24 \mathrm{~h}$. Following the incubation period, cells were treated with 400 or $3,200 \mu \mathrm{g} / \mathrm{ml}$ Avemar and the cells were incubated for a further $48 \mathrm{~h}$. Subsequently, the medium in each well was aspirated, and the cells were washed with ice-cold PBS and immediately lysed in 2-mercaptoethanol in RLT buffer from the RNeasy kit (Qiagen $\mathrm{GmbH}$, Hilden, Germany). Further RNA isolation was performed with the RNeasy kit as described by the manufacturer. Total isolated RNA was then quantified, and 100-ng samples of total RNA were reverse-transcribed into cDNA using a QuantiTect Reverse Transcription kit (Qiagen $\mathrm{GmbH}$ ), according to the manufacturer's protocol, along with random hexamers and oligo-(dT) ${ }_{16}$ primers included in the kit. RT was performed at $42^{\circ} \mathrm{C}$ for $30 \mathrm{~min}$. The total volume for each reverse transcription reaction was $20 \mu \mathrm{l}$. The generated cDNA was then used as the template for qPCR in a StepOnePlus ${ }^{\text {TM }}$ Real-Time PCR System (Thermo Fisher Scientific, Inc., Waltham, MA, USA). The qPCR was performed under the following conditions: 5 min initial denaturation at $94^{\circ} \mathrm{C}$, then 35 cycles of denaturation $\left(30 \mathrm{sec}\right.$ at $\left.94^{\circ} \mathrm{C}\right)$, annealing $\left(45 \mathrm{sec}\right.$ at $\left.58^{\circ} \mathrm{C}\right)$, extension $\left(45 \mathrm{sec}\right.$ at $72^{\circ} \mathrm{C}$ ), and a final extension at $72^{\circ} \mathrm{C}$ for $5 \mathrm{~min}$.

The reaction mixtures consisted of SYBR Green I (QuantiTect SYBR Green PCR kit; Qiagen GmbH), $300 \mu \mathrm{M}$ forward and reverse primers (final concentrations optimized during the assay setup), $100 \mathrm{nM}$ human UPL probe, and $2.5 \mu \mathrm{l}$ cDNA template. The sequences of the primer pairs are listed in Table I. The expression levels of the tested genes were normalized to that of GAPDH and presented as the fold change compared with the control group (17). All experiments were repeated three times.

Statistical analysis. All values are presented as the mean \pm standard error of mean. Data were analyzed using a one-way analysis of variance (ANOVA) followed by Dunnett's multiple comparisons test. Analyses were performed with GraphPad InStat v.10.0 software (GraphPad Software, Inc., La Jolla, CA, USA). $\mathrm{P}<0.05$ was considered statistically significant.

\section{Results}

VEGF is affected by Avemar in tumor cell lines. First, the maximum level of VEGF expression was determined in A549 cells stimulated by TNF- $\alpha$ and in PC3 and NCI-N87 cells stimulated by serum starvation. Basal VEGF protein levels were measured at 12, 24 and $48 \mathrm{~h}$ in HeLa cells, and the maximum induction of released VEGF protein was observed after $48 \mathrm{~h}$ without any stimuli (Fig. 1).

To determine the possible effects of Avemar on VEGF levels induced by the different stimuli for each cell line, all tumor cells were treated with 400, 800, 1,600 and 3,200 $\mu \mathrm{g} / \mathrm{ml}$ Avemar for 24 and $48 \mathrm{~h}$. In all cell lines, the inhibition of induced VEGF levels increased in a dose-dependent manner (Fig. 2). The increase in inhibition, as compared with the control group, was statistically significant in the HeLa and A549 cells that were treated with 3,200 $\mu \mathrm{g} / \mathrm{ml}$ Avemar for $48 \mathrm{~h}$ $(\mathrm{P}<0.001)$. No significant changes in VEGF inhibition were observed in the NCI-N87 and PC3 cells at either time point (P>0.05). In A549 and HeLa cells, RT-qPCR was performed to investigate whether the inhibition of VEGF levels occurred due to alterations at the transcript level. The results revealed consistent alterations in the mRNA (Fig. 3) and protein levels of VEGF $(\mathrm{P}<0.001)$. As shown in Fig. 3, Avemar treatment 
Table I. Primer pairs used for reverse transcription-quantitative polymerase chain reaction.

Primer sequences $\left(5^{\prime} \rightarrow 3^{\prime}\right)$

Gene name

Forward

Reverse

Cox-2

VEGF

GAPDH

\author{
TCACGCATCAGTTTTTCAAGA \\ AGGCCAGCACATAGGAGAGA \\ TCACCAGGGCTGCTTTTAACCT
}

TCACCGTAAATATGATTTAAGTCCAC
TTTCCCTTTCCTCGAACTGA
CACGCCACAGTTTCCCGGAG

Cox-2, cyclooxygenase 2; VEGF, vascular endothelial growth factor; GAPDH, glyceraldehyde-3-phosphate dehydrogenase.

A
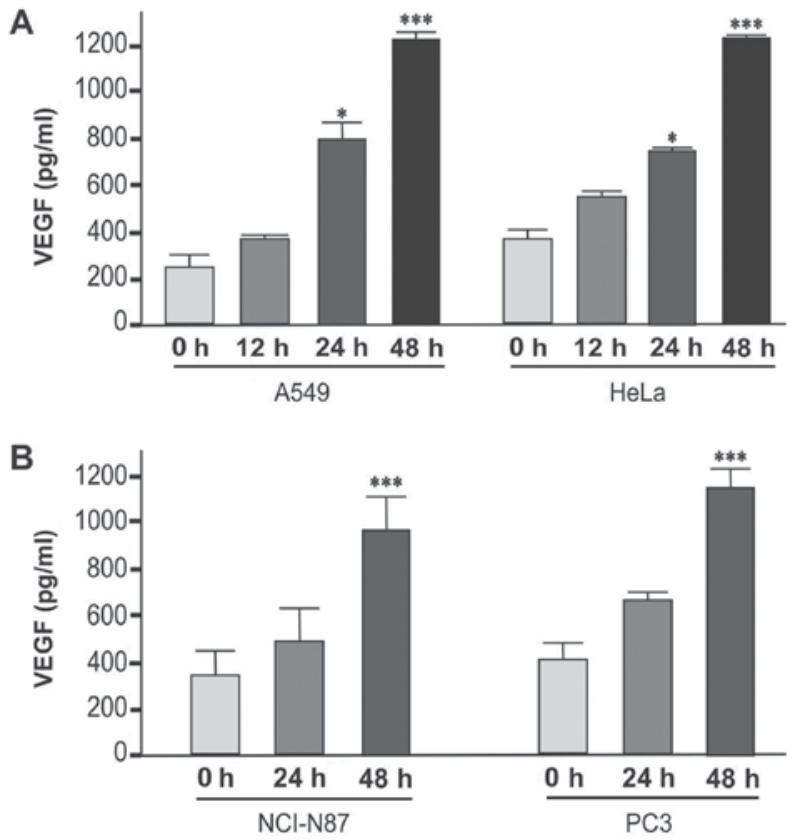

Figure 1. VEGF protein levels determined by ELISA. (A) A549 cells were incubated with tumor necrosis factor $\alpha(1,000 \mathrm{U} / \mathrm{ml})$ and HeLa cells were incubated without any stimuli for $48 \mathrm{~h}$. (B) NCI-N87 and PC3 cells were exposed to serum starvation for $48 \mathrm{~h}$. VEGF protein levels were measured by ELISA. Each data value indicates the mean \pm standard error of the mean of eight independent experiments. ${ }^{*} \mathrm{P}<0.05$ and ${ }^{* * * *} \mathrm{P}<0.001$ vs. control group $(0 \mathrm{~h})$ determined using a one-way analysis of variance followed by Dunnett's test. VEGF, vascular endothelial growth factor.

(3,200 $\mu \mathrm{g} / \mathrm{ml})$ yielded 3.2- and 3.4-fold decreases in VEGF mRNA levels in A549 and HeLa cells, respectively $(\mathrm{P}<0.001)$.

Cox-2 may be responsible for the inhibition by Avemar of $V E G F$ induction. It was next assessed whether Cox-2 was responsible for the VEGF inhibition following Avemar treatment in HeLa and A549 cells. Unstimulated HeLa cells and TNF- $\alpha$-stimulated A549 cells were treated with 400, 800, 1,600 and 3,200 $\mu \mathrm{g} / \mathrm{ml}$ Avemar for 24 and $48 \mathrm{~h}$, and Cox-2 protein levels were measured by ELISA. The inhibition of Cox-2 levels following Avemar treatment in HeLa and A549 cells increased in a time- and dose-dependent manner (Fig. 4). Compared with the control group, the amount of Cox- 2 protein decreased by $\sim 60 \%$ in HeLa and A549 cells $(\mathrm{P}<0.001)$. RT-qPCR was also performed to examine whether Avemar treatment was also associated with the inhibition of Cox-2 at the transcript level. RT-qPCR verified the ELISA results for Cox-2 levels, with Avemar treatment $(3,200 \mu \mathrm{g} / \mathrm{ml})$ yielding 4.3- and 4.6-fold decreases in Cox-2 mRNA levels in A549 and HeLa cells, respectively (Fig. 5).

\section{Discussion}

Avemar has been approved as a medical dietary supplement for cancer patients by Hungary's National Institute of Food Safety and Nutrition. It has been demonstrated to synergistically increase the effects of anticancer agents such as 5-fluorouracil (5-FU) and dacarbazine (18), and has also been shown to reduce the formation of metastases in certain animal models and to increase survival rates by inhibiting the proliferation of skin grafts $(19,20)$. In addition, the oral use of Avemar in patients with advanced colorectal cancer or high-risk melanoma inhibits the formation of tumor metastases and prolongs survival following chemotherapy and surgery $(13,14)$. The present study showed that Avemar exerts anti-angiogenic effects by inhibiting VEGF and Cox-2 gene expression in PC3, NCI-N87, HeLa and A549 cells. These findings highlight the anti-angiogenic effect of Avemar on cancer cell lines, and, to the best of our knowledge, this is the first report confirming this possible anti-angiogenic mechanism.

Angiogenesis is an important feature of malignant tumors. Newly formed tumor blood vessels provide the necessary nutrition for tumor growth as well as a means to spread to other organs. VEGF, the most widely accepted stimulator of angiogenesis, promotes the formation of new vessels by binding to VEGF receptors on the endothelial cells surrounding the blood vessels (21). In recent years, drugs that can block the VEGF pathway have become important components of cancer treatment. Another key regulator of angiogenesis is Cox-2, and there is a close association between the Cox-2 and VEGF pathways in the regulation of angiogenesis (22). Stimulating Cox-2 induces the activation and production of VEGF (23). Downregulation of the Cox-2 and VEGF pathways has been associated with the anti-angiogenic activity of polyphenols and polyphenol-rich foods in in vitro and in vivo models of angiogenesis (24-26). Therefore, it was hypothesized that Avemar, which includes a number of components, could reduce angiogenic responses in tumor cells and that this reduction may be mediated by decreases in Cox-2 and VEGF expression.

Tsujii et al (27) demonstrated that the overexpression of Cox-2 may lead to dedifferentiation, adhesion to the 


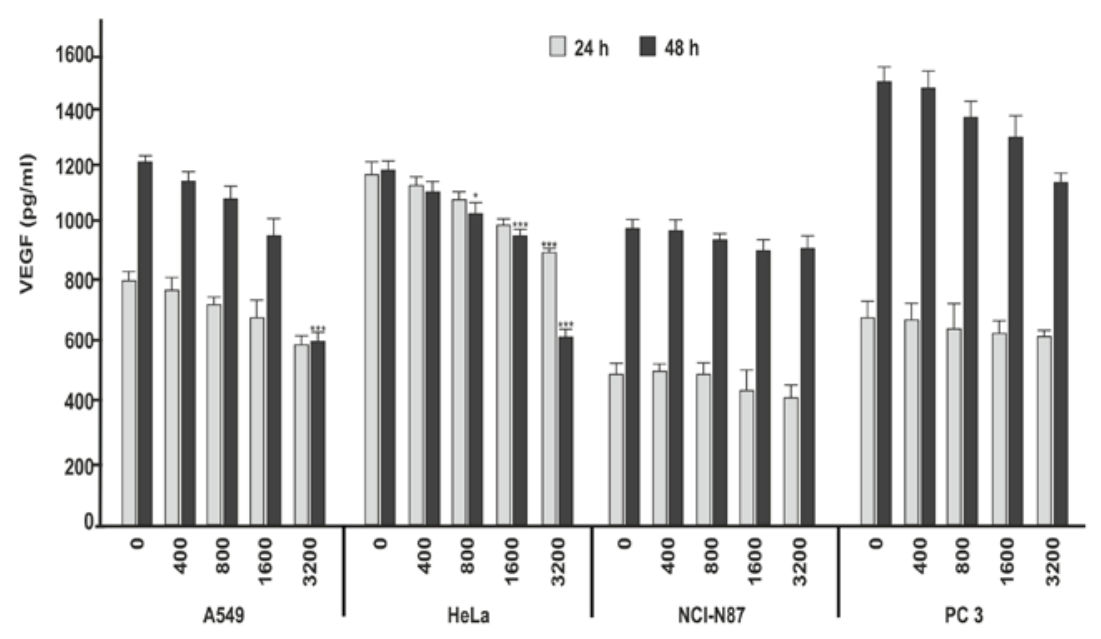

Figure 2. Avemar inhibits induced VEGF expression in A549 and HeLa cells, but not in NCI-N87 or PC3 cells. Following VEGF induction, all cells were treated with four different doses $(400,800,1,600$ and 3,200 $\mu \mathrm{g} / \mathrm{ml})$ of Avemar and VEGF expression was determined by ELISA. Each data point indicates the mean \pm standard error of the mean of eight independent experiments. ${ }^{*} \mathrm{P}<0.05$ and ${ }^{* * * *} \mathrm{P}<0.001$ vs. control group (no Avemar treatment) determined using a one-way analysis of variance followed by Dunnett's test. VEGF, vascular endothelial growth factor.

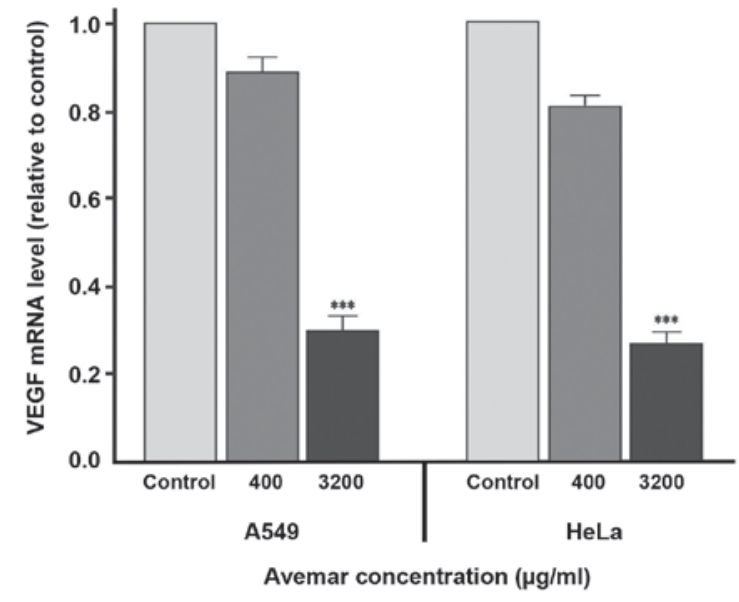

Figure 3. Avemar decreases the mRNA expression of VEGF in A549 and HeLa cells. GAPDH was used as an internal control to normalize the expression levels. Data are presented as the mean \pm standard error of the mean $(n=9)$. ${ }^{* * *} \mathrm{P}<0.001$ vs. control group determined using a one-way analysis of variance followed by Dunnett's test. VEGF, vascular endothelial growth factor.

extracellular matrix and inhibition of programmed cell death in intestinal cells. Although the precise mechanisms by which Cox-2 promotes tumor cell growth remain to be fully elucidated, it has been demonstrated that Cox-2 stimulates endothelial cell motility and tube formation in Caco-2 human colorectal cancer and HCA-7 human colonic adenocarcinoma cells by upregulating the production of pro-angiogenic factors, including VEGF. In a study performed by Sawaoka et al (28), which utilized an MKN45 xenograft model, it was demonstrated that the inhibition of Cox-2 by NS-398 (a selective Cox-2 inhibitor) suppressed the protein levels of VEGF and basic fibroblast growth factor, and that the angiogenic and apoptotic indexes were significantly associated. Furthermore, in a preclinical study by Mueller et al (11), the cytotoxic activity of Avemar was screened in a large panel of human tumor cell lines to evaluate its potential antitumor properties. The highest activity was found in neuroblastoma and ovarian cancer cell lines.

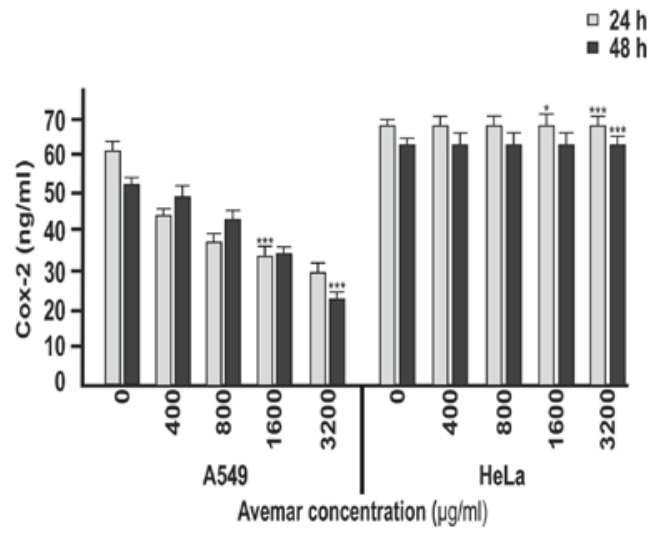

Figure 4. Avemar diminishes Cox-2 protein levels in A549 and HeLa cells. Cells were treated with the indicated doses of Avemar and Cox-2 protein levels were determined by ELISA. Each data point indicates the mean \pm standard error of the mean of eight independent experiments. ${ }^{*} \mathrm{P}<0.05$ and ${ }^{* * * *} \mathrm{P}<0.001$ vs. control group determined by a one-way analysis of variance followed by Dunnett's test. Cox-2, cyclooxygenase 2 .

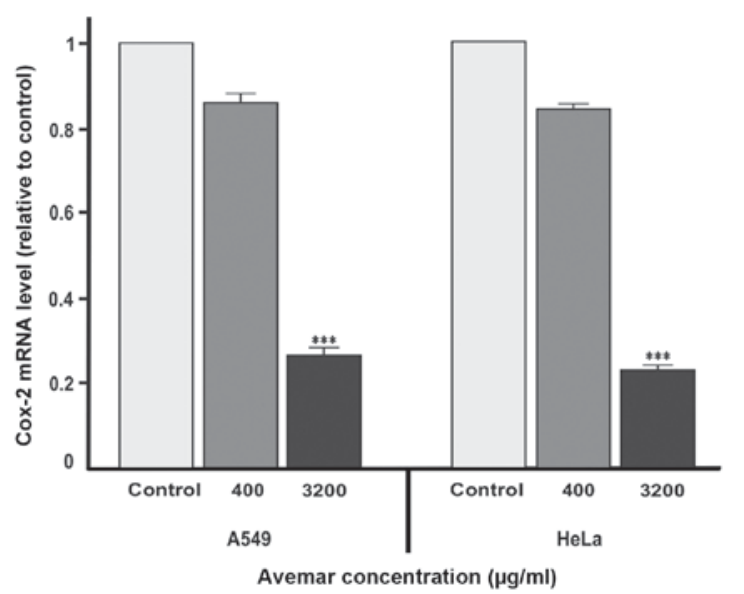

Figure 5. Avemar decreases the mRNA expression of Cox-2 in A549 and HeLa cells. GAPDH was used as an internal control to normalize expression levels. Data are presented as the mean \pm standard error of the mean $(n=9)$. ${ }^{* * *} \mathrm{P}<0.001$ vs. control group determined by a one-way analysis of variance followed by Dunnett's test. Cox-2, cyclooxygenase 2 . 
The half-maximal inhibitory concentrations of Avemar were $0.5 \mathrm{mg} / \mathrm{ml}$ in M2 (a gastric cancer cell line) and $0.4 \mathrm{mg} / \mathrm{ml}$ in A549 (a lung adenocarcinoma cell line). According to this, the results of the current study are in agreement with previous studies of Avemar that have demonstrated antitumor activity. We conclude that Avemar may exert anti-angiogenic activity by reducing VEGF and Cox-2 in tumor cells. However, further studies on how the products of Cox-2 mediate the transcriptional regulation of VEGF are required.

There are several limitations to the present study. First, the protein and gene levels of VEGF and Cox-2 were the only direct markers used in the assessment of angiogenesis. The extent and activity of other genes related to angiogenesis, such as matrix metalloproteinases (MMPs) and interleukins, requires further evaluation to better assess angiogenesis. The roles of MMP-2 and MMP-9 in angiogenesis have been explored in a variety of studies (29-31). Recently, Yang et al (32) demonstrated that Avemar significantly decreased the expression of MMP-2, but not MMP-1 or MMP-9, in SCC-4 oral cancer cells. In addition, the authors assayed the expression levels of urokinase-type plasminogen activator (uPA), an upstream activator of MMPs, which are typically associated with metastasis. The results of RT-PCR indicated that Avemar inhibited MMP-2 and UPA due to altering the transcript levels of these genes (31).

Future investigations are warranted on the combination of Avemar with other anticancer drugs, such as 5-FU and cisplatin, which may enhance its in vivo and in vitro anti-angiogenic and anti-proliferative activities.

In conclusion, the present study indicates that Avemar diminishes angiogenic activity in various tumor cell lines. This is mediated through decreased Cox-2 and VEGF levels. To the best of our knowledge, this is the first report examining the mechanism of the anti-angiogenic effect of Avemar on gastric, prostatic, cervical and lung cancer cells. We hope that this study will encourage further studies into the anti-angiogenic effects of Avemar alone and in combination with other anticancer agents.

\section{Acknowledgements}

The present study was supported by the Scientific Research Project Coordination Unit of Akdeniz University (grant no. 2014.01.0110.001). All experiments were carried out in the Cancer Molecular Biology Laboratory of the Biology Department of the Faculty of Science, Akdeniz University. The authors wish to thank Biropharma USA Inc. for donating the Avemar used in the study.

\section{References}

1. Folkman J: Angiogenesis in cancer, vascular, rheumatoid and other disease. Nat Med 1: 27-31, 1995 .

2. Adams RH and Alitalo $\mathrm{K}$ : Molecular regulation of angiogenesis and lymphangiogenesis. Nat Rev Mol Cell Biol 8: 464-478, 2007.

3. Bar J and Onn A: Combined anti-proliferative and anti-angiogenic strategies for cancer. Expert Opin Pharmacother 9: 701-715, 2008.

4. Cao Y: Angiogenesis: What can it offer for future medicine? Exp Cell Res 316: 1304-1308, 2010.

5. Mueller T and Voigt W: Fermented wheat germ extract-nutrional supplement or anticancer drug? Nutrition 10: 89, 2011.
6. Saiko P, Ozsvar-Kozma M, Madlener S, Bernhaus A, Lackner A Grusch M, Horvath Z, Krupitza G, Jaeger W, Ammer K, et al: Avemar, a nontoxic fermented wheat germ extract, induces apoptosis and inhibits ribonucleotide reductase in human HL-60 promyelocytic leukemia cells. Cancer Lett 250: 323-328, 2007.

7. Hidvégi M, Ráso E, Tömösközi-Farkas R, Paku S, Lapis K and Szende B: Effect of Avemar and Avemar C vitamin C on tumor growth and metastasis in experimental animals. Anticancer Res 18: 2353-2358, 1998

8. Demidov LV, Manziuk LV, Kharkevitch GY, Pirogova NA and Artamonova EV: Adjuvant fermented wheat germ extract (Avemar) nutraceutical improves survival of high-risk skin melanoma patients: A randomized, pilot, phase II clinical study with a 7-year follow-up. Cancer Biother Radiopharm 23: 477-482, 2008.

9. Heimbach JT, Sebestyen G, Semjen G and Kennepohl E: Safety studies regarding a standardized extract of fermented wheat germ. Int J Toxicol 26: 253-259, 2007.

10. Comin-Anduix B, Boros LG, Marin S, Boren J, Callol-Masot C, Centelles JJ, Torres JL, Angell N, Bassilian S and Cascante M: Fermented wheat germ extract inhibits glycolysis/pentose cycle enzymes and induces apoptosis through Poly(ADP-riboz) polymerase activation in Jurkat T-cell leukemia tumor cells. J Biol Chem 277: 46408-46414, 2002.

11. Mueller T, Jordan K and Voigt W: Promising cytotoxic profile of fermented wheat germ extract (Avemar®) in human cancer cell lines. J Exp Clin Cancer Res 30: 42, 2011.

12. Garami M, Schuler D, Babosa M, Borgulya G, Hauser P, Müller J, Paksy A, Szabó E, Hidvégi M and Fekete G: Fermented wheat germ extract reduces chemotherapy-induced febrile neutropenia in pediatric cancer patients. J Pediatr Hematol Oncol 26: 631-635, 2004.

13. Jakab F, Shoenfeld Y, Balogh A, Nichelatti M, Hoffmann A, Kahán Z, Lapis K, Mayer A, Sápy P, Szentpétery F, et al: A medical nutriment has supportive value in the treatment of colorectal cancer. Br J Cancer 89: 465-469, 2003.

14. Zhang JY, Xiao X, Dong Y, Wu J, Yao F and Zhou XH: Effect of fermented wheat germ extract with lactobacillus plantarum dy-1 on HT-29 cell proliferation and apoptosis. J Agric Food Chem 63: 2449-2457, 2015.

15. Koyama S, Sato E, Tsukadaira A, Haniuda M, Numanami H, Kurai M, Nagai S and Izumi T: Vascular endothelial growth factor mRNA and protein expression in airway epithelial cell lines in vitro. Eur Respir J 20: 1449-1456, 2002.

16. Şimşek E, Aydemir EA, İmir N, Koçak O, Kuruoğlu A and Fişkın K: Dimethyl sulfoxide-caused changes in pro- and anti-angiogenic factor levels could contribute to an anti-angiogenic response in HeLa cells. Neuropeptides 53: 37-43, 2015.

17. Livak KJ and Schmittgen TD: Analysis of relative gene expression data using real-time quantitative PCR and the 2(-delta delta C(T)) method. Methods 25: 402-408, 2001.

18. Hidvégi M, Rásó E, Tömösközi-Farkas R, Lapis $\mathrm{K}$ and Szende B: Effect of MSC on the immune response of mice. Immunopharmacology 41: 183-186, 1999.

19. Szende B, Rásó E, Hidvégi M, Tömösköziné FR, Paku S, Prónai L, Bocsi J and Lapis K: A new benzoquinone-containing antimetastatic product. Orv Hetil 139: 2893-2897, 1998 (In Hungarian).

20. Hidvégi M, Rásó E, Tömösközi-Farkas R, Szende B, Paku S, Prónai L, Bocsi J and Lapis K: MSC, a new benzoquinone-containing natural product with antimetastatic effect. Cancer Biother Radiopharm 14: 277-289, 1999.

21. Kerbel RS: Tumor angiogenesis. N Engl J Med 358: 2039-2049, 2008.

22. Taleb H, Morris RK, Withycombe CE, Maddocks SE and Kanekanian AD: Date syrup derived polyphenols attenuate angiogenic responses and exhibits anti-inflammatory activity mediated by VEGF and COX-2 expression in endothelial cells. Nutr Res 36: 636-647, 2016.

23. Costa C, Incio J and Soares R: Angiogenesis and chronic inflammation: Cause or consequence? Angiogenesis 10: 149-166, 2007.

24. Scoditti E, Calabriso N, Massaro M, Pellegrino M, Storelli C, Martines G, De Caterina R and Carluccio MA: Mediterranean diet polyphenols reduce inflammatory angiogenesis through MMP-9 and Cox-2 inhibition in human vascular endothelial cells: A potentially protective mechanism in atherosclerotic vascular disease and cancer. Arch Biochem Biophys 527: 81-89, 2012.

25. Corona G, Deiana M, Incani A, Vauzour D, Dessí MA and Spencer JP: Inhibition of $\mathrm{p} 38 / \mathrm{CREB}$ phosphorylation and Cox-2 expression by olive oil polyphenols underlies their anti-proliferative effects. Biochem Biophys Res Commun 362: 606-611, 2007. 
26. Medda R, Lyros O, Schmidt JL, Jovanovic N, Nie L, Link BJ, Otterson MF, Stoner GD, Shaker R and Rafiee P: Anti-inflammatory and anti-angiogenic effect of black raspberry extract on human esophageal and intestinal microvascular endothelial cells. Microvasc Res 97: 167-180, 2015.

27. Tsujii M, Kawano S and DuBois RN: Cyclooxygenase-2 expression in human colon cancer cells increases metastatic potential. Proc Natl Acad Sci USA 94: 3336-3340, 1997.

28. Sawaoka H, Tsuji S, Tsujii M, Gunawan ES, Sasaki Y, Kawano S and Hori M: Cyclooxygenase inhibitors suppress angiogenesis and reduce tumor growth in vivo. Lab Invest 79: 1469-1477, 1999.

29. Braunhut SJ and Moses MA: Retinoids modulate endothelial cell production of matrix-degrading proteases and tissue inhibitors of metalloproteinases (TIMP). J Biol Chem 269: 13472-13479, 1994.
30. Vacca A, Moretti S, Ribatti D, Pellegrino A, Pimpinelli N, Bianchi B, Bonifazi E, Ria R, Serio G and Dammacco F: Progression of mycosis fungoides is associated with changes in angiogenesis and expression of the matrix metalloproteinases 2 and 9. Eur J Cancer 33: 1685-1692, 1997.

31. Itoh T, Tanioka M, Yoshida $H$, Yoshioka $T$, Nishimoto $H$ and Itohara $\mathrm{S}$ : Reduced angiogenesis and tumor progression in gelatinase A-deficient mice. Cancer Res 58: 1048-1051, 1998 .

32. Yang MD, Chang WS, Tsaia CW, Wang MF, Chan YC, Chan KC, Lu MC, Kao AW, Hsu CM and Bau DT: Inhibitory effects of AVEMAR on proliferation and metastasis of oral cancer cells. Nutr Cancer 68: 473-480, 2016. 